\title{
PREPARATION OF THE ELECTROSPUN POLYVINYLIDENE FLUORIDE / POLYVINYL ALCOHOL SCAFFOLD AS A POTENTIAL TISSUE REPLACEMENT
}

\author{
Mohd Syahir Anwar Hamzah ${ }^{1}$, Nurul Amira Ab Razak ${ }^{1}$, Celine NG ${ }^{1}$, \\ AKmal Hafiszi Abdul Azize ${ }^{1}$, Jumadi Abdul SUKOR ${ }^{1}$, SoON ChIn FHONG ${ }^{2}$, \\ MOHD SAFIEE IDRIS ${ }^{3}$ AND NADIRUL HASRAF MAT NAYAN ${ }^{2 *}$ \\ ${ }^{1}$ Faculty of Engineering Technology, Universiti Tun Hussein Onn Malaysia, \\ Pagoh Higher Educatiopn Hub, Jalan Panchor, Pagoh, Johor, 84600, Malaysia \\ ${ }^{2}$ Microelectronics and Nanotechnology-Shamsuddin Research Centre, \\ Universiti Tun Hussein Onn Malaysia, Parit Raja, Johor, 86400, Malaysia \\ ${ }^{3}$ Faculty of Technical and Vocational Education, Universiti Tun Hussein Onn \\ Malaysia, Parit Raja, Johor, 86400, Malaysia \\ *Corresponding author: nadirul@uthm.edu.my
}

(Received: 12 $2^{\text {th }}$ April 2020; Accepted: $30^{\text {th }}$ September 2020; Published on-line: $4^{\text {th }}$ January 2021)

\begin{abstract}
Polyvinylidene fluoride (PVDF), a piezoelectric material, is commonly used in tissue engineering due to its potential for mimicking the electrical microenvironment of biological conditions for tissue development. In this present research, polyvinyl alcohol (PVA) was introduced into electrospun PVDF fabrication through an electrospinning process, aiming to enhance the nanofibrous membrane's biocompatibility properties by improving the hydrophilicity properties to act as an artificial tissue scaffold. The electrospun PVDF/PVA membranes are found to be optimum at a PVDF-to-PVA ratio of 90:10 due to its excellent mechanical, morphological, and hydrophilicity conductivity properties. Fourier transform infrared (FTIR) spectroscopy verified strong hydrogen bonding interaction formed between the fluorine group of PVDF with oxygen-containing in the hydroxyl group of PVA. In-vitro cell culture showed that the enhanced hydrophilic property of electrospun PVDF/PVA could significantly enhance the cell growth. These positive results indicated that the scaffold could be implemented as artificial tissue material for tissue engineering applications.
\end{abstract}

ABSTRAK: Polivinilidena fluorida (PVDF) adalah bahan piezoelektrik yang biasa digunakan dalam kejuruteraan tisu kerana potensinya menyerupai keadaan persekitaran mikro-elektrik biologi bagi perkembangan tisu. Dalam penyelidikan ini, polivinil alkohol (PVA) diperkenalkan ke dalam fabrikasi pintalan-elektro PVDF melalui proses pemintalan-elektro, yang bertujuan bagi mengembangkan sifat biokompatibiliti membran nanogentian dengan meningkatkan sifat hidrofilik bagi menjadi perancah tisu tiruan. Membran pintalan-elektro PVDF / PVA didapati optimum pada nisbah PVDF-ke-PVA, 90:10 kerana sifat kekonduksian, mekanikal, morfologi dan hidrofiliknya yang sangat baik. Spektroskopi transformasi inframerah Fourier (FTIR) mengesahkan interaksi ikatan hidrogen yang kuat terbentuk antara kumpulan fluoro PVDF dengan oksigen yang terkandung dalam kumpulan hidroksil PVA. Kultur sel secara in-vitro menunjukkan bahawa sifat hidrofilik pintalan-elektro PVDF / PVA dapat meningkatkan pertumbuhan sel secara signifikan. Hasil positif ini menunjukkan bahawa perancah ini dapat digunakan sebagai bahan tisu buatan bagi aplikasi kejuruteraan tisu.

KEYWORDS: polyvinylidene fluoride; polyvinyl alcohol; electrospinning; tissue engineering; nanofiber scaffold 


\section{INTRODUCTION}

Damaged tissues or organs can lead to fatal health problems. When natural repair is impossible, doctors use tissue or organ transplantation to restore damaged biological systems' structures and functions [1-3]. Transplant demand currently exceeds availability, generating unmet clinical needs. The U.S. Department of Health and Human Services estimated that 20 people die every day waiting for transplants inaccessible due to organ or tissue scarcity. Tissue engineering has long been known as a promising alternative to donor tissues, often in short supply. Nanofiber-based scaffolds are preferred for nerve, skin, cartilage, and other soft tissue replacement applications among various scaffolds. The tissue scaffold provides a temporary matrix to promote tissue regeneration by remodeling tissue functions and promoting cell growth in artificial microarchitecture [2-4]. For clinical applications, tissue scaffold's mechanical properties should be enough to withstand internal and external forces depending on tissue and organ types. The tissue scaffold must be biocompatible with good hydrophilic characteristics and a high ratio of surface-to-volume to speed up cell seeding and nutrient diffusion through the artificial tissue structures [3].

Electrospinning is a simple technique commonly used due to its ability to be manufactured with controllable surface morphology, flexible porosity, and optimum mechanical efficiency, which is favorable for the preparation of nanofiber scaffolds [5]. Studies show that the alignment and diameter of electrospinning fibers can be modified to suit the design of a broad range of cells/tissues, favorably influencing cell formation, degradation rates, physical condition, and artificial scaffold mechanical properties [6-7]. The material selection is important because the performance of the electrospinning process depends on the polymer solution's ability to form a fine charged jet while applying a strong electric field. An electroactive material is a potential choice, especially a piezoelectric material, to recreate the electrical microenvironment of cell or tissue growth [8-9]. It can produce electrical stimulation under body movement action without an external power source. Electrical stimulation can control several cellular functions, including the reorganization of their cytoskeleton, differentiation, intracellular pathway activation, protein secretion, and gene expression [9].

Polyvinylidene fluoride (PVDF) is a piezoelectric polymer with semi-crystalline structure and could exist in different possible polymorphism phases which are $\alpha, \beta, \gamma$, and $\delta$ [10]. Previous study on the electrospinning of PVDF shows that the dominant orientation crystalline structure of polar $\beta$-phase crystal along the fiber axis, which gives high electric conductivity behavior and makes it suitable for tissue engineering [11]. The major drawback of PVDF in tissue engineering is that it is not a hydrophilic polymer that can lead to low cell affinity and inflammatory effect towards the host tissue or organ. For that reason, many researchers have incorporated PVDF with hydrophilic fillers such as polyurethane (PU), trifluoroethylene (TrFE), chitosan, graphene oxide (GO), and polyhedral oligomeric silsesquioxane-epigallocatechin gallate (POSS-EGCG) conjugate to increase its water absorption ability and specific cell recognition sites without losing its mechanical integrity [12-15]. The study of modified PVDF with trifluoroethylene (TrFE) for in-vitro cell culture shows better support for Schwann cells and myelination growth than the neat PVDF scaffold alone [16]. Other studies showed success in manufacturing microporous PVDF membranes for nerve tissue engineering by covalently immobilising L-lysine on the surface of the PVDF membrane [17].

Polyvinyl alcohol (PVA) is a semicrystalline hydrophilic polymer easily soluble in water, commonly used in biomedical applications due to its biocompatibility with most tissue types, ability to absorb protein molecules, ability to follow minimum cell adhesion, 
and high stability at large temperature ranges [18-19]. Other than that, the crystalline structure consists of the hydroxyl group, which makes a high degree of miscibility with other materials and serves as a cell-bind recognition site at the scaffold throughout the process of regeneration [20]. PVA structure also has a negative charge and an excellent ability to absorb cation molecules. It is also tasteless and odorless, has strong mechanical strength, high capacity to shape scaffolds, good biocompatibility, and biodegradability in human tissue and fluid [21]. Therefore, PVA can be combined with PVDF to obtain a scaffold with desired physical properties suitable for cell and tissue regeneration processes.

In this work, electrospun PVDF/PVA scaffolds were fabricated using single phase horizontal type electrospinning (illustrated in Figure 1). The electrospun samples were systematically characterized in terms of mechanical property, wettability, swelling percentage, morphological condition, conductivity performance, and FTIR spectroscopy. The in-vitro cell behavior was also examined by culturing human dermal fibroblast (HDF) cells on top of the electrospun samples before being analyzed using MTT assay and SEM micrograph. To date, no single-phase PVDF / PVA nanofiber scaffold studies using the electrospinning technique have been published.

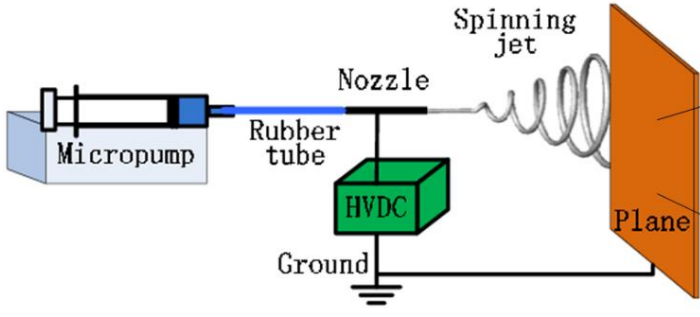

Horizontal electrospinning

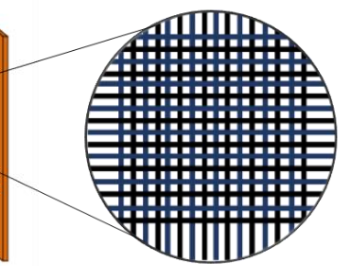

Electrospun PVDF/PVAscaffold

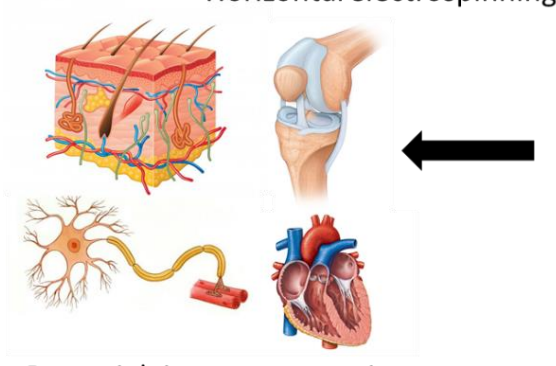

Potential tissue regeneration

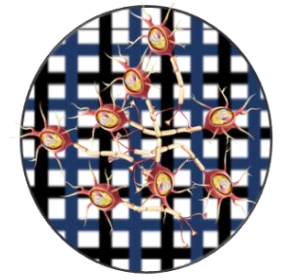

Cell seeding/culturing

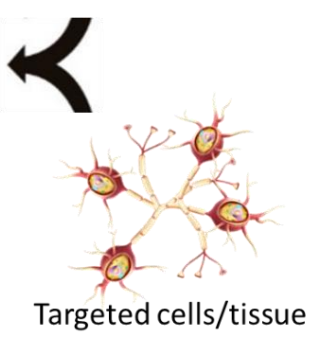

Targeted cells/tissue

Fig. 1: Illustration of horizontal of electrospinning process and the potential application of electrospun PVDF/PVA membranes in tissue engineering.

\section{MATERIALS AND METHODOLOGY}

\subsection{Materials}

All materials used in this work are analytical grade materials. PVDF with molar weight of $534,000 \mathrm{~g} / \mathrm{mol}$ and PVA with molar weight of more than $89,000 \mathrm{~g} / \mathrm{mol}$ were purchased from Sigma Aldrich. Dimethyl sulfoxide (DMSO) with molar weight of $84.17 \mathrm{~g} / \mathrm{mol}$ and phosphate buffered saline (PBS) were supplied by Merck.

\subsection{Preparation of Electrospun PVDF/PVA}

The PVDF and PVA were dissolved in $5 \mathrm{~mL}$ DMSO solution forming $0.15 \%(\mathrm{w} / \mathrm{v})$ concentration with varied PVDF-to-PVA ratio and six electrospun PVDF/PVA nanofiber samples were prepared (Table 1). The electrospinning apparatus was set up horizontally. 5- 
$\mathrm{mL}$ polymer solution was placed in a $5-\mathrm{mL}$ plastic syringe with $23 \mathrm{G}$ needle size and an injection rate of $1.0 \mathrm{ml} / \mathrm{h}$. The needle tip of the syringe was connected to a $5-\mathrm{kV}$ voltage power with the tip-to-collector distance of $13 \mathrm{~cm}$.

Table 1: PVDF-to-PVA ratio used in fabrication process

\begin{tabular}{cc}
\hline PVDF-to-PVA ratio & Type of sample \\
\hline $100: 0$ & 100PVDF/0PVA or Neat PVDF \\
$95: 5$ & 95PVDF/5PVA \\
$90: 10$ & $90 \mathrm{PVDF} / 10 \mathrm{PVA}$ \\
$85: 15$ & $85 \mathrm{PVDF} / 15 \mathrm{PVA}$ \\
$80: 20$ & 80PVDF/20PVA \\
$75: 25$ & 75PVDF/25PVA \\
\hline
\end{tabular}

\subsection{Field Emission Scanning Electron Microscope (FESEM)}

The FESEM model JSM-7800F, brand JEOL was used for morphological observation of PVDF/PVA nanofiber. The nanofiber was sputter coated with gold for $30 \mathrm{~s}$ at $18 \mathrm{Ma}$ with $100 \times-10000 \times$ magnification. From the magnified image, the diameter of nanofiber was determined using Image J software to analyze at least 100 different fibers.

\subsection{Tensile Test}

Tensile test was conducted to obtain the stress-strain graph using a universal tester according to ASTM D-882 (Instron, 2018). The testing of the sample was performed at a strain rate of $10 \mathrm{~mm} / \mathrm{min}$ and load strength of $5 \mathrm{kN}$ at room temperature. Five replications were conducted for each sample.

\subsection{Water Contact Angle (WCA)}

The WCA was measured using the sessile drop method adopted from ASTM D7334 08 , where the image of $1 \mu 1$ of deionized water dropped on the surface of the samples was captured using the video contact angle system (VCA Optima, Ast Products Inc.) after 3s. Three replications were tested for each sample.

\subsection{Degree of Swelling}

The samples were dried in the oven at $70{ }^{\circ} \mathrm{C}$ until a constant weight was achieved to eliminate water before testing. Then, the nanofiber was immersed in $10 \mathrm{ml}$ of PBS and the weight of the swollen nanofiber was recorded in the time interval of 1 day, to 5 days. Three replications were conducted for each sample. The degree of swelling for each sample was calculated using Eq. 1.

$$
\text { Degree of Swelling }(\%)=\frac{w_{f}-w_{i}}{w_{f}} \times 100
$$

where, $w_{f}$ represents the weight of swollen nanofiber at a predetermined time and $w_{i}$ is the initial weight of the nanofiber.

\subsection{Conductivity}

The conductivity of PVDF/PVA nanofiber was measured using a multimeter (SANWA, Japan). The nanofiber with a thickness of $1 \mathrm{~cm}$ and diameter of $0.4 \mathrm{~cm}$ was placed between two blades that were planted on a nonconductive substrate. Three resistance measurements were taken for each specimen and the conductivity was calculated using Eq. 2.

$$
\text { Conductivity }=\frac{1}{\rho}=\frac{l}{R A}
$$


where, $\rho$ represents the electrical resistivity through a specific area, $R$ is the resistance given by the sample, $l$ signifies the sample thickness used, and $A$ is the surface area of the sample.

\subsection{Fourier Transform Infrared Spectroscopy (FTIR)}

FTIR spectroscopy (Perkin Elmer Frontier) was used to determine the structural and interaction characteristic of pristine PVDF and the optimum PVDF/PVA nanofibers within the wavelength from 400 to $4000 \mathrm{~cm}^{-1}$. The sample of nanofiber was prepared into a size of $1 \mathrm{~cm} \times 1 \mathrm{~cm}$ and placed in the holder and the total pressure applied was set before processing the sample.

\subsection{In-vitro Culture of Human Dermal Fibroblast (HDF) Cells}

In this experiment, the 5th to 10th passages of HDF cells were used and cultured in Tflasks comprising DMEM medium supplemented with $10 \%$ (v/v) fetal bovine serum (FBS), $1 \%(\mathrm{v} / \mathrm{v})$ L-glutamine, and $1 \%(\mathrm{v} / \mathrm{v})$ penicillin/streptomycin. The cells were incubated at $37^{\circ} \mathrm{C}$ with $5 \% \mathrm{CO}_{2}$ and the medium was refreshed every 3 days. The nanofibrous samples were seeded with HDF cell suspension at $1 \times 10^{4}$ cells $/ \mathrm{ml}$ in 24 -well culture plates. The cells were allowed to attach for at least 10 minutes and the medium was refreshed with a new culture medium before the samples were subjected to incubation periods depending on assay requirements [22].

\subsection{Cytotoxicity: MTT Assay}

MTT assay was performed to evaluate the cell proliferation and metabolic activity by quantifying the purple formazan crystals absorbance that represents the amount of survived cell after 24 and $48 \mathrm{hrs}$ of incubation period. The nanofibrous samples were transferred into new wells and the MTT reagent was added into each well. Then, the samples were incubated for $4 \mathrm{hrs}$ until formazan crystals were formed. The absorbance of the solution was measured at $570 \mathrm{~nm}$ using a microplate reader [22].

\subsection{Scanning Electron Microscope (SEM)}

The morphological characteristic of HDF cultured cells was examined using SEM after $24 \mathrm{hrs}$. The samples were washed with PBS and fixed with $2.5 \%$ glutaraldehyde at $4{ }^{\circ} \mathrm{C}$ overnight. Then, the samples were dehydrated using a series of graded alcohol and allowed to vacuum dry before being sputter coated with gold. Then, the samples were perceived using SEM (Leo Supra 50VP Field Emission SEM, Carl Zeiss, Germany) at the accelerating voltage of $15 \mathrm{kV}$.

\section{RESULTS AND DISCUSSION}

\subsection{Morphology Characterization}

Figure 2 shows the fibrous nanostructure fibers of pure PVDF and electrospun PVDF/PVA with its diameter distribution. Figure 2(a)-1(c) show that the diameter of nanofibers decreased from 210 to $161 \mathrm{~nm}$ as the PVA ratio achieved 10\% (w/v) of PVDF polymer solution. 

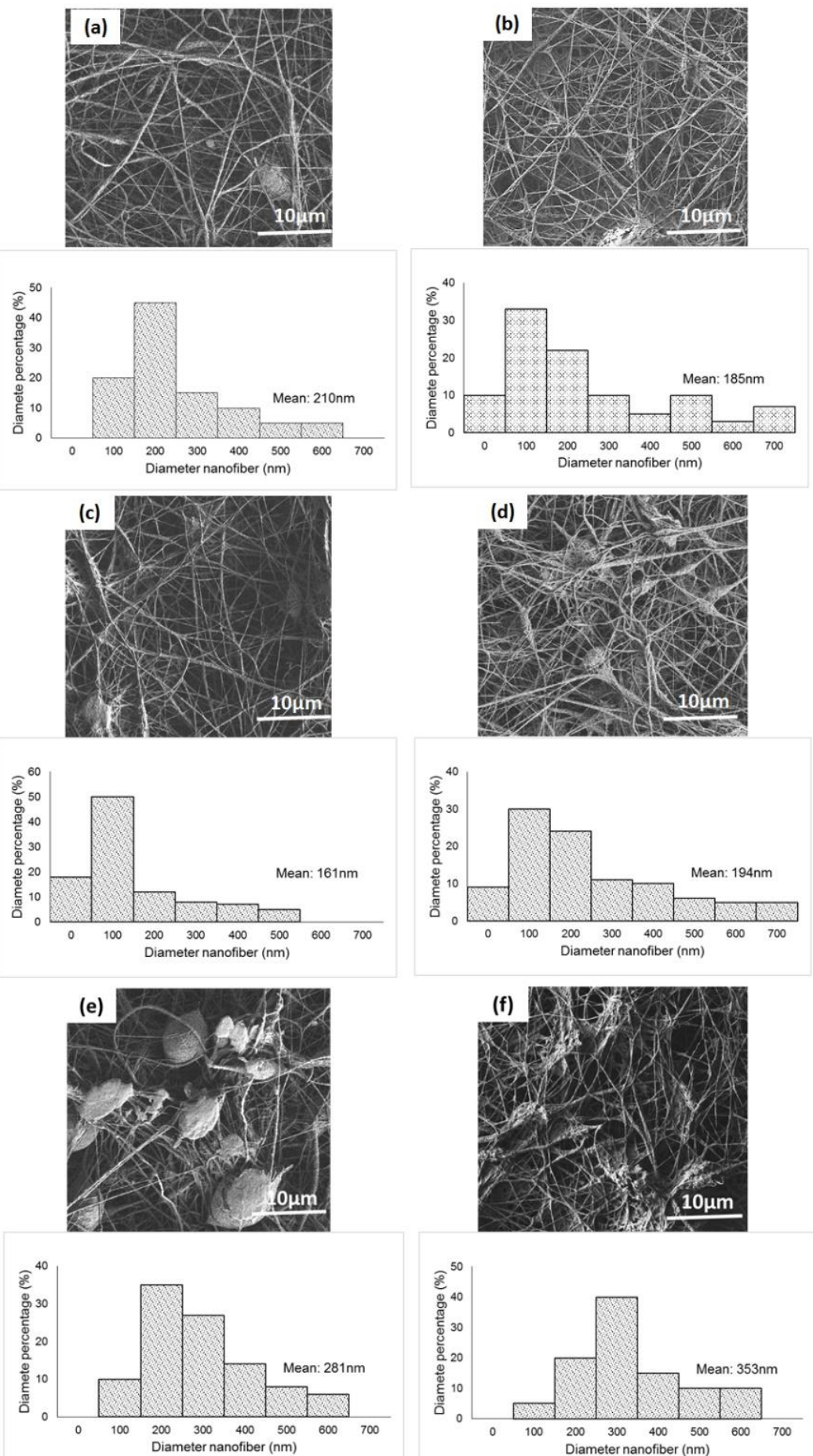

Fig. 2: FESEM micrograph and diameter distribution of electrospun samples of (a) 100PVDF/0PVA, (b) 95PVDF/5PVA, (c) 90PVDF/10PVA, (d) 85PVDF/15PVA, (e) 8 0PVDF/20PVA, and (f) 75PVDF/25PVA at 1.00k magnification.

The small amount of PVA inclusion has significantly effect on the viscosity of PVDF polymer solution, which leads to better dispersion resulting from sufficient jet stretching time and volatilization of solvents. However, significant morphological changes were observed as the PVA ratio increased from $15 \%$ in 85PVDF/15PVA to $25 \%$ in 75PVDF/25PVA. Further ratio alteration caused more bead-on-string formation resulting in non-homogeneous surface occurring due to low voltage that does not allow uniform stretching of polymer that is capable of promoting uniform nanofibers. Beads occur due to 
incomplete solvent evaporation due to the reduction of dielectric potential resulting from the low viscosity of conductive PVDF polymer solution. In tissue engineering applications, the diameter size of the electrospun will significantly influence the fibrous surface area and volume for cell attachment, where smaller diameter can provide high density for cell cultivation [23-24]. This advantage will greatly benefit the cells or tissues that have limited capacity for endogenous regeneration and/or replacement of defective cells such as those in the brain and nervous system.

\subsection{Tensile Strength Characterization}

Mechanical properties of electrospun nanofiber are crucial elements in tissue engineering, especially during surgeries. An ideal electrospun nanofiber should be durable, flexible, and able to sustain high pressure when tissue begins to infiltrate into the scaffold, and increase growth [25]. The tensile properties of the tested samples are summarized in Fig. 3. The tensile strength and Young's modulus of the neat electrospun PVDF was $1.33 \pm 0.7 \mathrm{MPa}$ and $9.61 \pm 0.2 \mathrm{MPa}$, respectively. The alteration of PVDF-to-PVA ratio from $5 \%$ to $10 \%$ increased the tensile strength and Young's modulus significantly. However, the higher inclusion of PVA ( $15 \%$ to $25 \%$ ) drastically reduced the mechanical integrity of the electrospun nanofiber. This reduction may be caused by the loss of PVDF phases in the formulation as shown in the SEM micrograph. The higher reduction of PVDF ratio produced an unstable electrospinning process that led to the high number of beads that affect the structural integrity of the electrospun fiber's performance. Sample 90PVDF/10PVA has an optimal tensile strength of $1.72 \pm 0.6 \mathrm{MPa}$ and Young's modulus of $22.03 \pm 0.5 \mathrm{MPa}$. Previous study reported that the tensile strength for natural soft collagenous tissues such as cartilage, cornea, nerve, and skin is around 1 to $10 \mathrm{MPa}[3,23]$. Therefore, based on these findings, the modified electrospun nanofiber meets the requirement as a potential tissue scaffold.

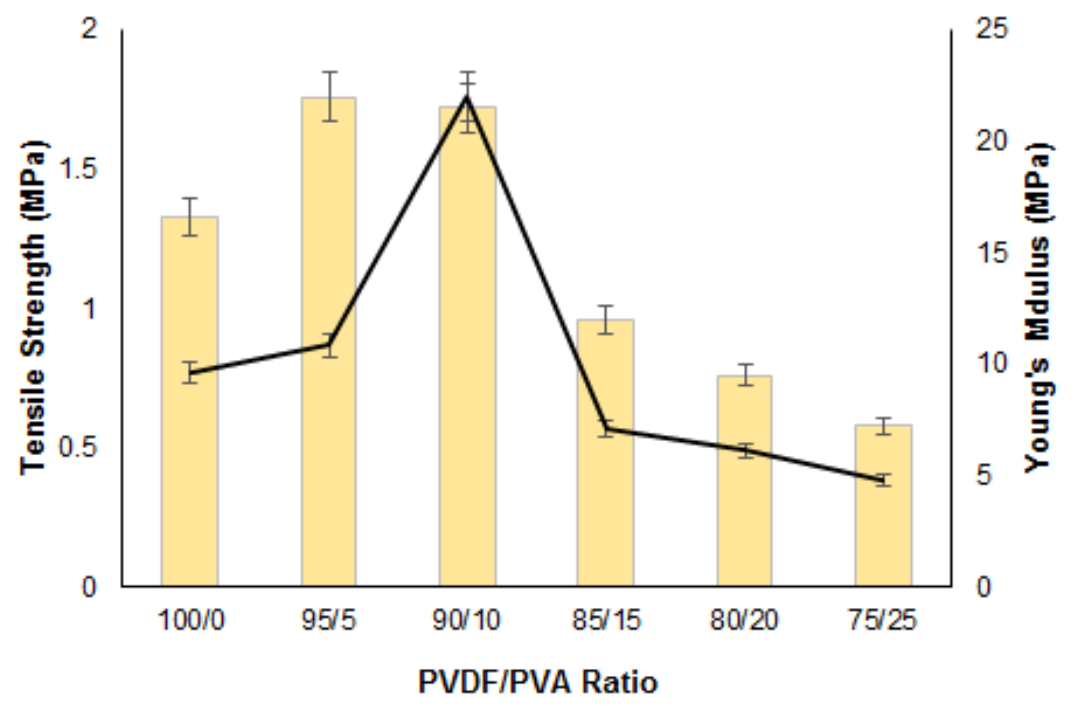

Fig. 3: The tensile strength and Young's modulus of neat PVDF and electrospun PVDF/PVA.

\subsection{Water Contact Angle (WCA)}

In tissue engineering, the surface of the artificial tissue scaffold is the first component that comes into contact with the biological structure, which allows the desired outcome of tissue growth if it is biocompatible. The WCA is one of the methods used to study the sample's surface performance in terms of wettability [26-27]. Figure 4 presents the WCA 
and the images of water dropped on the electrospun samples. The WCA for 100PVDF/OPVA was $130.50^{\circ}$, indicating the super hydrophobicity of the electrospun sample surface contributed by its low surface energy and hydrophobic property. However, the addition of PVA monomer in the PVDF formulation significantly reduced the WCA in achieving the hydrophilic value of more than $90^{\circ}$. The PVA monomer introduced hydroxyl and carbonyl groups into the electrospun PVDF surface and changed the polarity of surfaces by increasing the specific hydrogen bond as well as the electrostatic forces with water molecules. Figure 4 (d)-(f) show that the higher increase of PVA addition slightly increased the WCA values due to the increase in bead-string formation that results in rougher surfaces compared to the PVA at 5\% and 10\% ratio as shown by FESEM micrograph in Figure 2 (d)-(f). Generally, higher surface roughness leads to low water drop-material contact area, which will interrupt water-fiber interface and further reduce the contact area between the artificial scaffold and biological specimen. Hence, low WCA will be favorable for tissue engineering applications because it will maximize the output outcome when the scaffold is allocated at the lesion site of tissues [26,28].
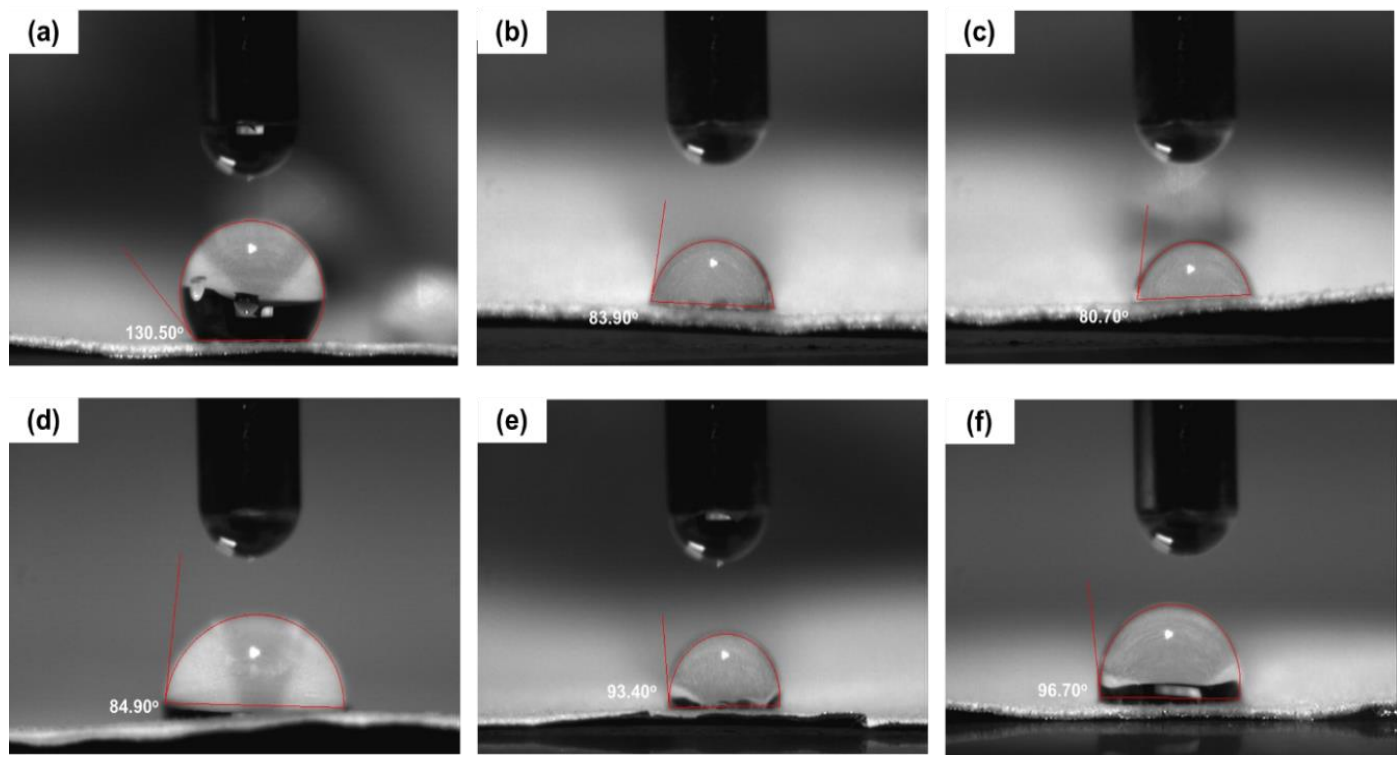

Fig. 4: Surface contact angle of (a) 100PVDF/0PVA, (b) 95PVDF/5PVA, (c) 90PVDF/10PVA, (d) 85PVDF/15PVA, (e) 80PVDF/20PVA, and (f) 75PVDF/25PVA.

\subsection{Degree of Swelling}

The ability of the sample to absorb water molecules plays a major role during cell growth, especially during cell seeding. It will also influence the potential of the electrospun composite to maintain its shape during the application. Figure 5 presents the degree of swelling percentage of the neat PVDF and its modification containing electrospun PVA. The results reveal that the inclusion of PVA strongly influences the swelling capacity of the electrospun nanofiber as the degree of swelling increased from $4.76 \pm 1.3 \%$ (for 100PVDF/0PVA) to $69.84 \pm 1.5 \%$ (for 90PVDF/10PVA) after $24 \mathrm{hrs}$ of immersion in PBS at $\mathrm{pH}$ 7.4. The increase of the swelling percentage could be attributed to the fine inter- and intra-polymer reactions and the addition of hydrophilic groups in the electrospun PVDF/PVA. This observation corroborates the WCA experiment, where the presence of PVA increased the specific interaction between the electrospun surfaces as a substrate to water molecule through the hydrogen bond. Increases can also be seen after 24 hours of 
immersion, showing a positive indication to sustaining the swelling activity during the healing process as it will affect the signaling mechanism of molecules and nutrients. [29].

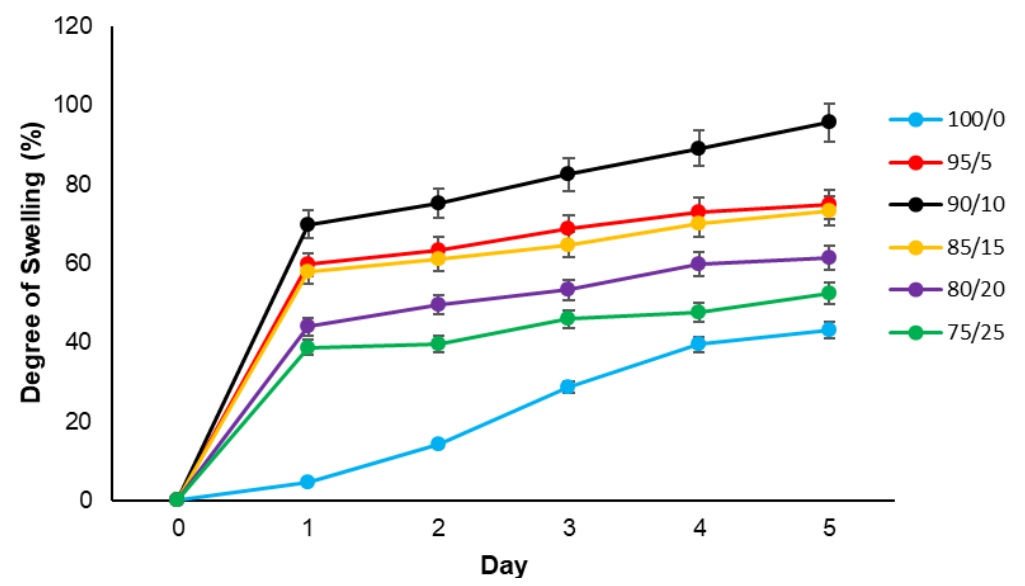

Fig. 5: Percentage of swelling for neat PVDF and electrospun PVDF/PVA.

\subsection{Conductivity Analysis}

The conductivity of each sample was calculated using Equation 2 and is presented in Table 2. The conductivity of the neat PVDF nanofiber was $4.023 \times 10^{-4} \mathrm{~S} / \mathrm{cm}$. The conductivity of electrospun PVDF was contributed to by the formation of a $\beta$-phase that plays an important role in piezoelectric and pyroelectric performance [30-31]. The conductivity increased with the increasing amount of PVA until $10 \%$ inclusion at $5.991 \times 10^{-4} \mathrm{~S} / \mathrm{cm}$. This might be due to the electrospinning process causing the dielectric polarization of the dielectric PVA monomer. It has led to the increase in intermolecular distance and the mobility of the chains, which accelerates the orientation of the modified polymer molecules into more crystalline structures. Besides, this improvement was also contributed to by the uniform dispersion and proper interaction of PVDF and PVA forming a uniform, porous, and well-fibered structure, which will act as a charge carrier (hole) motion for the conducting electrical charges [32]. However, higher inclusion reduced the conductivity due to the higher loss of PVDF monomer and increased bed-string fiber, thus causing low electrical motion carrier throughout the electrospun samples.

Table 2: The conductivity of neat PVDF and PVDF/PVA electrospuns.

\begin{tabular}{cc}
\hline PVDF/PVA Ratio & Conductivity (S/cm) \\
\hline $100 / 0$ & $4.023 \times 10^{-4} \pm 0.021$ \\
$95 / 5$ & $4.834 \times 10^{-4} \pm 0.013$ \\
$90 / 10$ & $5.991 \times 10^{-4} \pm 0.026$ \\
$85 / 15$ & $4.917 \times 10^{-4} \pm 0.023$ \\
$80 / 20$ & $4.123 \times 10^{-4} \pm 0.015$ \\
$75 / 25$ & $3.533 \times 10^{-4} \pm 0.016$ \\
\hline
\end{tabular}

In general, the bioactive conductive scaffolds give huge advantages during cell attachment and proliferation where it will improve intracellular electrical signaling to sensitive cells to increase cytoplasmic content, especially for fibroblasts, neurons, myoblasts, and osteoblasts cell types [33]. Previous study reported that scaffolds with conductivity from 1.21 to $4.54 \times 10^{-4} \mathrm{~S} / \mathrm{cm}$ demonstrate excellent work in enhancing myoblasts proliferation, while scaffolds conductivity around $3.5 \times 10^{-3} \mathrm{~S} / \mathrm{cm}$ show good growth activities on cardiomyocyte and neuron cells [34]. It was also reported that the scaffolds with conductivity from $6.5 \times 10^{-4}$ to $1.4 \times 10^{-3} \mathrm{~S} / \mathrm{cm}$ show good adhesion and 
proliferation of cells using rabbit adipose-derived mesenchymal stem cells [35]. Accordingly, the electrospun PVDF/PVA prepared in this study might be suitable for electrically sensitive tissue applications. Among the formulations, 90PVDF/10PVA is considered to be a proper condition for further testing due to its excellent morphology, and mechanical and wettability properties.

\subsection{FTIR Analysis}

The chemical composition of PVDF, PVA, and PVDF-PVA blended ratio 90:10 nanofiber was characterized using the FTIR spectrum. Figure 6 (a) shows a strong peak at $1400 \mathrm{~cm}^{-1}$ that corresponds to the $\mathrm{C}-\mathrm{H}$ antisymmetric deformation, representing typical PVDF nanofiber characteristics. Meanwhile, strong peaks at 1072, 1174, and $1275 \mathrm{~cm}^{-1}$ correspond to the vibration of $\mathrm{C}-\mathrm{F}$ bond that was found in the PVDF nanofiber [36]. Figure 6 (b) shows the spectrum for PVA film. The characteristic band at peaks of 3398 and 3430 $\mathrm{cm}^{-1}$ indicate the interconnection between the hydrogen bond of the hydroxyl functional group $(\mathrm{O}-\mathrm{H})$ [30-31]. The interaction between PVDF and PVA is depicted in Figure 6 (c), which shows the hydrogen bond interconnection between the two materials that can be observed through the new peak at $3363 \mathrm{~cm}^{-1}$, which indicates the association of PVDF fluorine groups to the hydroxyl group of PVA [37]. A new peak at $2850 \mathrm{~cm}^{-1}$ was found in the PVDF/PVA transmission profile which donates from the $\mathrm{C}-\mathrm{H}$ bond. Other strong peaks at 1071,1275 , and $1400 \mathrm{~cm}^{-1}$, found in the PVDF/PVA spectrum, indicate the possible stretching vibration of $\mathrm{C}-\mathrm{F}$ from $\mathrm{PVDF}$ and $\mathrm{C}-\mathrm{O}-\mathrm{C}$ bond from PVDF/PVA $[14,18,36]$. Meanwhile, the vibration bands occurring at 839 and $831 \mathrm{~cm}^{-1}$ indicate $\mathrm{CF}_{2}$ bending and $\mathrm{CF}_{2}$ rocking corresponding to the $\alpha$ and $\beta$ phases $[18,38]$.

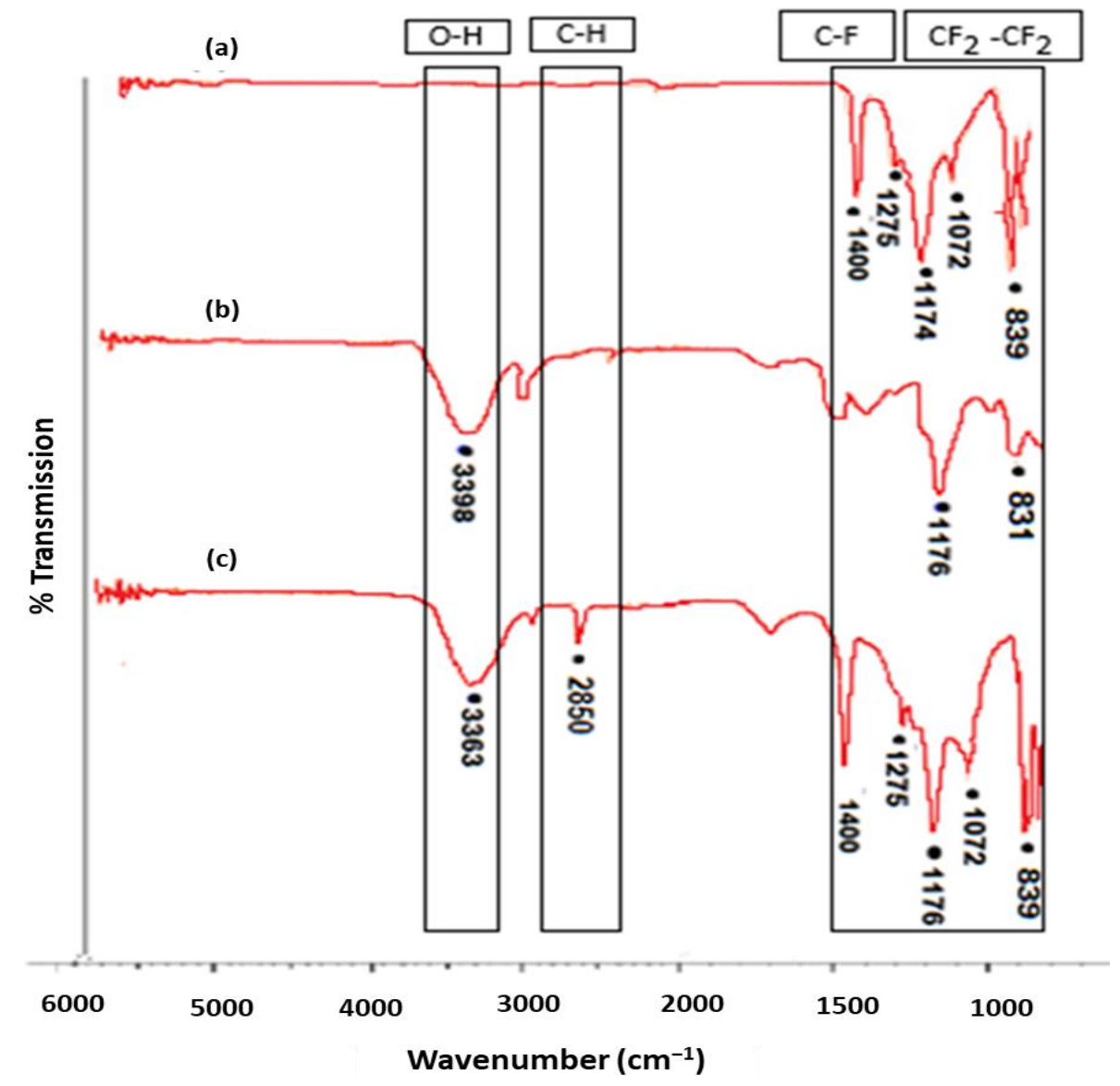

Fig. 6: FTIR spectra of electrospun (a) PVDF, (b) PVA and (c) PVDF/PVA nanofiber. 


\subsection{In-vitro Cytotoxicity}

MTT assay was carried out to evaluate the biocompatibility of the neat PVDF and electrospun PVDF/PVA using HDF cells and compared to control negative (normal culturing) and control positive (Trixton-X). Figure 7 (a) shows that the proliferation of cells on the electrospun PVDF/PVA was higher than that of the neat electrospun PVDF, indicating that the composite polymer might have enhanced the adhesion and differentiation of HDF cells. Besides, the PVA inclusion in electrospun PVDF/PVA showed better attachment and proliferative behavior of cells after $24 \mathrm{hrs}$ of seeding process compared to neat electrospun PVDF, as presented in Fig. 7 (b) and (c). The micrographs of HDF cells displayed the complete stretching morphology for both scaffold and well spreading and interaction onto electrospun PVDF/PVA surfaces compared to the neat electrospun PVDF. The addition of PVA have altered the wettability and introduced biochemical signals onto the electrospun surface, which makes it favorable for specific cells-substrate interactions [39]. Furthermore, the ability of the electrospun PVDF/PVA to absorb fluid acts as an important reason for the proliferative performance of HDF cells, because it aids in transferring metabolic products and nutrients efficiently during the cell culture.
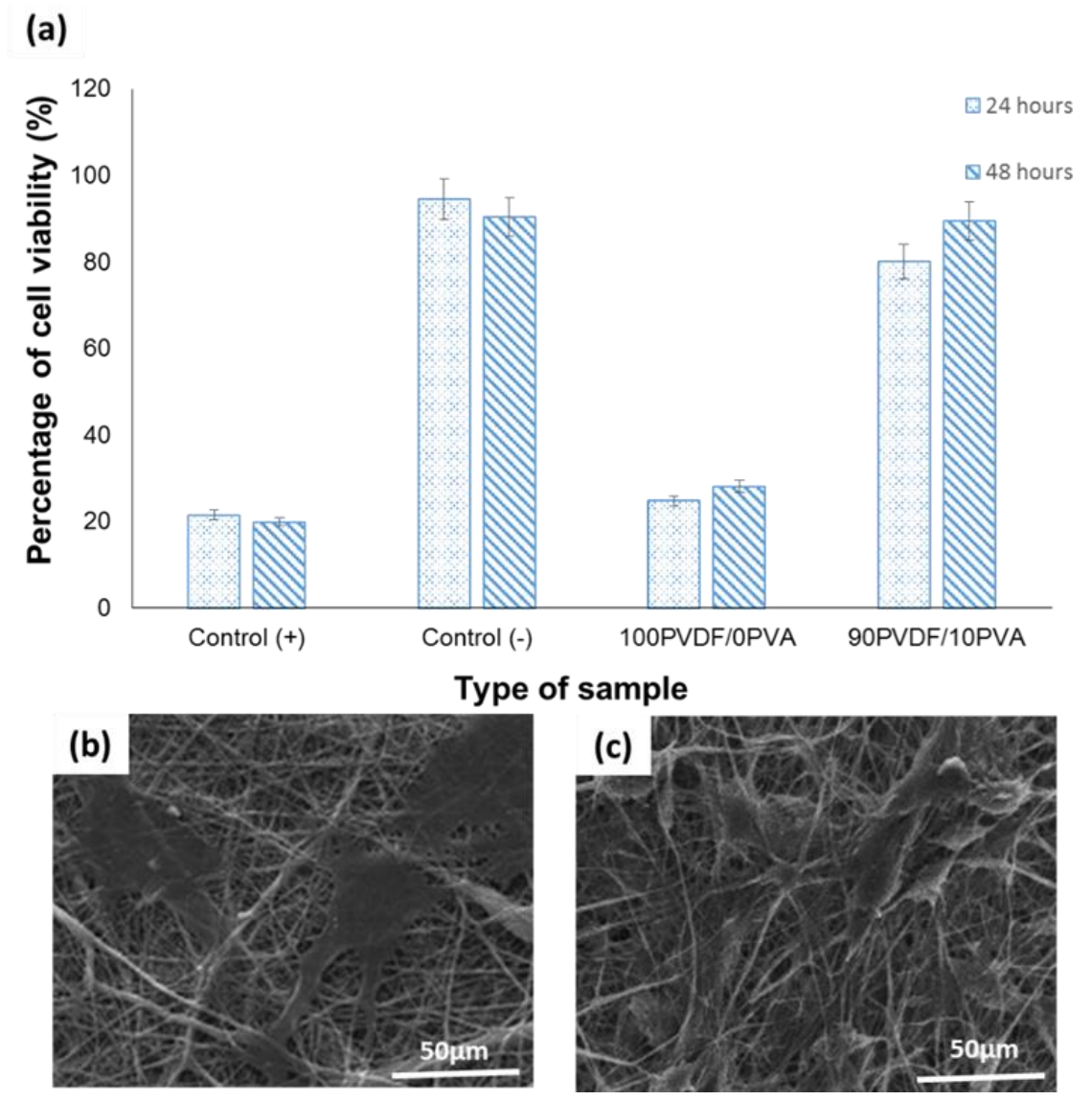

Fig. 7: (a) Percentage viability of HDF cells using MTT assay; SEM micrograph of HDF cells after 24 hrs onto electrospun (b) 100PVDF/PVA and (c) 90PVDF/10PVA at $1.5 \mathrm{k}$ magnification. 


\section{CONCLUSION}

Here, nanofibrous membrane scaffolds of PVDF/PVA were developed by electrospinning with an average fiber diameter ranging from 160 to $180 \mathrm{~nm}$. A PVDF-toPVA ratio of 90:10 (90PVDF/10PVA) was found for optimal electrospun nanofiber with excellent mechanical, wettability, and electrical properties. Other studies assisted the FTIR spectra in indicating the excellent interaction between the PVDF chain and PVA monomer. PVDF/PVA has strong biocompatibility and is nontoxic to HDF cells, where the modified nanofibrous scaffold successfully assisted the process of cell differentiation and proliferation. Future work is required to reassure the impact of the nanofibrous membrane on specific targeted tissue engineering applications.

\section{ACKNOWLEDGEMENT}

This work is supported by the Universiti Tun Hussein Onn Malaysia (UTHM) through the Geran Penyelidikan Pascasiswazah (GPPS-Vot number H458) as well as Ministry of Higher Education Malaysia (KPT) through the Fundamental Research Grant Scheme FRGS/1/2019/TK10/UTHM/03/1 (FRGS-K220) and Malaysia Technical University Network Grant Scheme (MTUN-K243 and K124).

\section{REFERENCES}

[1] Okutan N. Terzi P, Altay F. (2014) Affecting parameters on electrospinning process and characterization of electrospun gelatin nanofibers. Food Hydrocolloids, 39: 19-26. https://doi.org/10.1016/j.foodhyd.2013.12.022

[2] Meng ZX, Xu XX, Zheng W, Zhou HM, Li L, Zheng YF, Lou X. (2011) Preparation and characterization of electrospun PLGA/gelatin nanofibers as a potential drug delivery system. Colloids and Surfaces B: Biointerfaces, 84(1): 97-102. https://doi.org/10.1016/j.colsurfb.2010.12.022

[3] Khoo W, Koh CT, Lim SC. (2017) Synthetic and natural fibrous scaffolds for soft tissue engineering applications. Journal of Mechanical Engineering, 4, 223-233. Retrieved from https://jmeche.uitm.edu.my/

[4] Savaşer S, Kınay ÖB, Kara BY, Cay P. (2019) Organ transplantation logistics: a case for Turkey. OR Spectrum, 41(2): 327-356.

[5] Li WJ, Laurencin CT, Caterson EJ, Tuan RS, Ko FK. (2002) Electrospun nanofibrous structure: a novel scaffold for tissue engineering. Journal of Biomedical Materials Research: An Official Journal of The Society for Biomaterials, The Japanese Society for Biomaterials, and The Australian Society for Biomaterials and the Korean Society for Biomaterials, 60(4): 613-621. https://doi.org/10.1002/jbm.10167

[6] Franco RA, Nguyen TH, Lee BT. (2011) Preparation and characterization of electrospun PCL/PLGA membranes and chitosan/gelatin hydrogels for skin bioengineering applications. Journal of Materials Science: Materials in Medicine, 22(10): 2207. https://doi.org/10.1007/s10856-011-4402-8

[7] Hackett JM, Dang TT, Tsai EC, Cao X. (2010) Electrospun biocomposite polycaprolactone/collagen tubes as scaffolds for neural stem cell differentiation. Materials, 3(6): 3714-3728. https://doi.org/10.3390/ma3063714

[8] Shuai C, Zeng Z, Yang Y, Qi F, Peng S, Yang W, He C, Wang G, Qian G. (2020) Graphene oxide assists polyvinylidene fluoride scaffold to reconstruct electrical microenvironment of bone tissue. Materials \& Design, 190: 108564. https://doi.org/10.1016/j.matdes.2020.108564

[9] Kitsara M, Blanquer A, Murillo G, Humblot V, Vieira SDB, Nogués C, Ibáñez E, Esteve J, Barrios L. (2019) Permanently hydrophilic, piezoelectric PVDF nanofibrous scaffolds 
promoting unaided electromechanical stimulation on osteoblasts. Nanoscale, 11(18): 89068917. https://doi.org/10.1039/C8NR10384D

[10] Shao HJF, Wang H, Lin T. (2015) Effect of electospinning parameter and polymer conccentration on mechanical to electrical energy conversion of randomly oriented electrospun poly(vinylidene fluoride) nanofiber mats. Advances, 5(19): 14345-50. https://doi.org/10.1039/C4RA16360E

[11] Ribeiro C, Correia DM, Ribeiro S, Sencadas V, Botelho G, Lanceros-Méndez S. (2015) Piezoelectric poly (vinylidene fluoride) microstructure and poling state in active tissue engineering. Engineering in Life Sciences, 15(4): 351-356. https://doi.org/10.1002/elsc.201400144

[12] Jeong HG, Han YS, Jung KH, Kim YJ. (2019) Poly (vinylidene fluoride) composite nanofibers containing polyhedral oligomeric silsesquioxane-epigallocatechin gallate conjugate for bone tissue regeneration. Nanomaterials, 9(2): 184. https://doi.org/10.3390/nano9020184

[13] Hamzah MSA, Azize AHA, Yusof S, Noor SM, Nayan NHM. (2019) Electrospinning and controlled release studies of polyvinylidene fluoride/pectin electrospun loaded with crocin as neuroprotective membrane prospect. Proceedings of National Innovation \& Invention Competition 2019 (pp. 335-338). Johor, Malaysia: Universiti Tun Hussein Onn Malaysia, ISBN: 978-967-2389-31-6

[14] Park JA, Cho KY, Han CH, Nam A, Kim JH, Lee SH, Choi JW. (2019) Quaternized amphiphilic block copolymers/graphene oxide and a poly (vinyl alcohol) coating layer on graphene oxide/poly (vinylidene fluoride) electrospun nanofibers for superhydrophilic and antibacterial properties. Scientific Reports, 9(1): 383. https://doi.org/10.1038/s41598-01836479-w

[15] Moradi R, Karimi-Sabet J, Shariaty-Niassar M, Koochaki M. (2015) Preparation and characterization of polyvinylidene fluoride/graphene superhydrophobic fibrous films. Polymers, 7(8): 1444-1463. https://doi.org/10.3390/polym7081444

[16] Wu S, Chen MS, Maurel P, Lee YS, Bunge MB, Arinzeh TL. (2018) Aligned fibrous PVDFTrFE scaffolds with Schwann cells support neurite extension and myelination in vitro. Journal of Neural Engineering, 15(5): 056010. https://doi.org/10.1088/17412552/aac77f

[17] Young TH, Lin UH, Lin DJ, Chang HH, Cheng LP. (2009) Immobilization of L-lysine on microporous PVDF membranes for neuron culture. Journal of Biomaterials Science, Polymer Edition, 20(5-6): 703-720. https://doi.org/10.1163/156856209X426574

[18] Nkhwa S, Lauriaga KF, Kemal E, De, S. (2014) Poly (vinyl alcohol): physical approaches to designing biomaterials for biomedical applications. In Conference Papers in Science (Vol. 2014). Hindawi. https://doi.org/10.1155/2014/403472

[19] Uslu I, Daştan H, Altaş A, Yayli A, Atakol O, Aksu ML. (2007) Preparation and characterization of pva/boron polymer produced by an electrospinning technique. ePolymers: 7(1). DOI: https://doi.org/10.1515/epoly.2007.7.1.1568

[20] Teodorescu, M., Bercea, M., \& Morariu, S. (2019). Biomaterials of PVA and PVP in medical and pharmaceutical applications: Perspectives and challenges. Biotechnology Advances, 37(1): 109-131. https://doi.org/10.1016/j.biotechadv.2018.11.008

[21] Kumar A, Han SS. (2017) PVA-based hydrogels for tissue engineering: A review. International Journal of Polymeric Materials and Polymeric Biomaterials, 66(4): 159-182. https://doi.org/10.1080/00914037.2016.1190930

[22] Hamzah MSA, Razak SIA, Kadir MRA, Bohari SPM, Nayan NHM. (2020) Fabrication and evaluation of polylactic acid/pectin composite scaffold via freze extraction for tissue engineering. Journal of Polymer Engineering, 40(5). DOI: https://doi.org/10.1515/polyeng2019-0377

[23] Hamzah MSA, Austad A, Razak SIA, Nayan NHM. (2019) Tensile and wettability properties of electrospun polycaprolactone coated with pectin/polyaniline composite for drug delivery application. International Journal of Structural Integrity, 10(5): 704-713. https://doi.org/10.1108/IJSI-04-2019-0033 
[24] Pezeshki-Modaress M, Zandi M, Rajabi S. (2018) Tailoring the gelatin/chitosan electrospun scaffold for application in skin tissue engineering: An in vitro study. Progress in Biomaterials, 7(3): 207-218. https://doi.org/10.1007/s40204-018-0094-1

[25] Alhasssan ZA, Burezq YS, Nair R, Shehata N. (2018) Polyvinylidene difluoride piezoelectric electrospun nanofibers: Review in synthesis, fabrication, characterizations, and applications. Journal of Nanomaterials, 2018: 1-12. https://doi.org/10.1155/2018/8164185

[26] Saudi A, Rafienia M, Zargar Kharazi A, Salehi H, Zarrabi A, Karevan M. (2019) Design and fabrication of poly (glycerol sebacate)-based fibers for neural tissue engineering: Synthesis, electrospinning, and characterization. Polymers for Advanced Technologies, 30(6): 14271440. https://doi.org/10.1002/pat.4575

[27] Raffaini G, Ganazzoli F. (2007) Understanding the performance of biomaterials through molecular modeling: crossing the bridge between their intrinsic properties and the surface adsorption of proteins. Macromolecular Bioscience, 7(5): 552-566. https://doi.org/10.1002/mabi.200600278

[28] Menzies KL, Jones L. (2010) The impact of contact angle on the biocompatibility of biomaterials. Optometry and Vision Science, 87(6): 387-399. https://doi.org/10.1097/OPX.0b013e3181da863e

[29] Pan JF, Liu NH, Sun H, Xu F. (2014) Preparation and characterization of electrospun PLCL/poloxamer nanofibers and dextran/gelatin hydrogels for skin tissue engineering. PLoS One, 9(11). https://doi.org/10.1371/journal.pone.0112885

[30] Rianjanu A, Winardianto B, Munir M, Kartini I, Triyana K. (2016) Electrical conductivity improvement of polyvinyl alcohol nanofiber by solvent vapour treatment. International Journal on Advanced Science, Engineering and Information Technology, 6(5): 675-681. https://doi.org/10.18517/IJASEIT.6.5.1055

[31] Aqeel SM, Wang Z, Than L, Sreenivasulu G, Zeng X. (2015) Poly (vinylidene fluoride)/poly (acrylonitrile)-based superior hydrophobic piezoelectric solid derived by aligned carbon nanotubes in electrospinning: fabrication, phase conversion and surface energy. RSC Advances, 5(93): 76383-76391. https://doi.org/10.1039/C5RA11584A

[32] Shahini, A., Yazdimamaghani, M., Walker, K. J., Eastman, M. A., Hatami-Marbini, H., Smith BJ, Ricci JL, Madihally SV, Vashaee D, Tayebi L. (2014) 3D conductive nanocomposite scaffold for bone tissue engineering. International Journal of Nanomedicine, 9: 167. https://doi.org/10.2147/IJN.S54668

[33] Balint R, Cassidy NJ, Cartmell SH. (2014) Conductive polymers: Towards a smart biomaterial for tissue engineering. Acta Biomaterialia, 10(6): 2341-2353. https://doi.org/10.1016/j.actbio.2014.02.015

[34] Zhao YH, Niu CM, Shi JQ, Wang YY, Yang YM, Wang HB. (2018) Novel conductive polypyrrole/silk fibroin scaffold for neural tissue repair. Neural Regeneration Research, 13(8): 1455. https://doi.org/10.4103/1673-5374.235303

[35] Dong R, Zhao X, Guo B, Ma PX. (2016) Self-healing conductive injectable hydrogels with antibacterial activity as cell delivery carrier for cardiac cell therapy. ACS Applied Materials \& Interfaces, 8(27): 17138-17150. https://doi.org/10.1021/acsami.6b04911

[36] Park MJ, Gonzales RR, Abdel-Wahab A, Phuntsho S, Shon HK. (2018) Hydrophilic polyvinyl alcohol coating on hydrophobic electrospun nanofiber membrane for high performance thin film composite forward osmosis membrane. Desalination, 426: 50-59. https://doi.org/10.1016/j.desal.2017.10.042

[37] Boccaccio T, Bottino A, Capannelli G, Piaggio P. (2002) Characterization of PVDF membranes by vibrational spectroscopy. Journal of Membrane Science, 210(2): 315-329. https://doi.org/10.1016/S0376-7388(02)00407-6

[38] Martins P, Lopes AC, Lanceros-Mendez S. (2014) Electroactive phases of poly (vinylidene fluoride): Determination, processing and applications. Progress in Polymer Science, 39(4): 683-706. https://doi.org/10.1016/j.progpolymsci.2013.07.006

[39] Ghasemi-Mobarakeh L, Prabhakaran MP, Morshed M, Nasr-Esfahani MH, Ramakrishna S. (2008) Electrospun poly ( $\varepsilon$-caprolactone)/gelatin nanofibrous scaffolds for nerve tissue engineering. Biomaterials, 29(34): 4532-4539.

https://doi.org/10.1016/j.biomaterials.2008.08.007 